\title{
Women and Money Management: Problematising Working-class Subjectivities in French Television Programmes During and after the Post-war Boom
}

\author{
By Laetitia Overney
}

\begin{abstract}
This article looks at French television during and after the post-war period to explore the relationships that programmes systematically established between home-making in social housing, housekeeping money management and women. It sheds light on the gendered dimensions of thrift and dwelling. French 1960's Television reflected a range of urban transformations characteristic of the period: the development of high-rise estates, social housing, shopping centers. How should people inhabit these new environnements, new structures of dwelling and new services in order to keep up with regular household expenses such as paying rent, utility bills, buying food or covering child rearing costs?

Since the $19^{\text {th }}$ century, women had generally managed household budgets as part of the everyday domestic cultures. These heavy financial responsibilities were relayed by televised documentaries prompting questions about the types of in/ appropriate activities and attitudes, knowledges and expertises shown on mainstream TV at the time. Television was constantly problematizing working-class subjectivities through women's voice. On the one hand, television reports showed women always counting the money and thrifting in order to control the household comsumption and to avoid debts. In the documentaries I analyse, the women describe in detail their economic problems and moral economies they are conditioned to operate within. On the other hand, TV programmes were replete with the specialist home economics tips that were meant to spread normative representations of dwelling in order to educate housewives.

Women's activities are tied to the welfare state which is revealed in all its complexity, controlling with one hand the rationalisation of domestic budgets and practices, and, with the other, improving living conditions and protecting individuals against vulnerabilities.
\end{abstract}

Keywords: Social Housing, Working Class, Women, Television Archives, Moral Economy, Consumption, Home Account Book, Welfare State.

Overney, Laetitia: "Women and Money Management: Problematising Working-class Subjectivities in French Television Programmes During and after the Post-war Boom", Culture Unbound, Volume 11, issue 3-4, 2019: 443-465. Published by Linköping University Electronic Press: http://www.cultureunbound.ep.liu.se 


\section{Introduction}

This article looks back at French television during the post-war period to explore the relationships that programmes systematically established between home-making in social housing, housekeeping money management and women. In the 1960s and 1970s, television reflected a range of urban transformations characteristic of the times: the development of high-rise estates, social housing, shopping centres, and comfort and domestic appliances in the home (Rudolph 2014). Women were portrayed as central figures in these new homes (Canteux 2014): they were the ones interviewed by journalists while their husbands were at work and they were filmed crossing concrete slabs to do their shopping, or dusting and polishing their comfortable and modern flats.

In Europe between the two wars, public authorities set middle-class women the task of progressing and this mission was passed on through the teaching of home economics at school, exhibitions, catholic associations, women's press and books on home-making (Clarke 2005, Segalen 1994, de Caigny 2005). These media circulated information on standards of health and comfort, new lifestyles and rules for rationalising household budgets. ${ }^{1}$ In the 1950s, these messages more directly targeted working-class women who were moving into new social housing $\left(\mathrm{HLM}^{2}\right)$ tower blocks and who had for a long time been in charge of housekeeping and family budget management (Hoggart 1957). This economic and domestic function is an important aspect of their daily practices. In what way does French post-war television portray and replay a traditional role that goes back to working-class milieus in the nineteenth century?

Television systematically underlined the working-class origins of the women filmed in the new social housing. Social housing tower blocks were a brand new domestic work space for these women, who had only just vacated unsanitary homes with no running water or amenities and who were discovering a new universe and new facilities. ${ }^{3}$ How were women to inhabit these new environments and dwellings, with new services such as social centres, youth centres and launderettes, in a manner that would allow them to keep up with regular household expenses such as rent, utilities, food and raising children? With these new homes, there was a significant increase in the portion of the family budget reserved for rent. How were they to juggle between these different expenses so as to meet the needs of all the family and also "properly" look after the home? What was the best way to spend their benefit payments? These were the sort of questions that television was asking.

As soon as a programme discussed new social housing, the question of family budgeting was raised, and it was women who were under the spotlight. This article looks at how television intricately linked home-making, money management and women to a backdrop of social housing. My challenge is to highlight the gende- 
red dimensions of dwelling and thrift. At the intersection of class and gender, the sociological analysis sheds light on working-class economics and women practices during the post-war period and in the urban context of high-rise estates. I examine the dissemination and popularisation, in and through TV, of the normative home-making values and moral economies of the working class. Television portrayed a normative family model (close link between women and the home and strict control of expenditure) alongside emancipatory considerations. The heavy financial responsibilities of women were highlighted, prompting questions about the types of in/appropriate activities and attitudes, knowledge and expertise shown on television at the time. On the one hand, the documentaries and reports I analyse always show women counting money and being thrifty in order to control household consumption and avoid getting into debt. Television programmes were awash with specialist home economics tips that were designed to spread normative representations of the dwelling in order to educate housewives. On the other hand, the women describe in detail their economic problems and their own moral values with regard to effective home-making. They are vocal critics of social-housing landlords who increase rent and service charges.

Women's shifting roles at the time have to be considered in the context of the late nineteenth century's France, when (like in other Western countries), housing and family gradually became areas of legitimate women's involvement in public

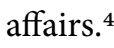

This paper uses archival research, focusing on specific genre(s), documentaries and news reports that were popular at the time and which dealt with new social housing. Between conformism and emancipation, television was a new vector allowing women to express their views in public. It revealed their thoughts, problems and hopes. I ask what significance women's public participation had on TV in the 1960's and 1970's; how it concerned working-class women - and how was female activism represented - especially in relation to thrift and dwelling? In the first section I will show how television relayed educational and normative messages to working-class women; in the second part of the article I explore the avenues of emancipation that these broadcasts nevertheless opened up. My analysis of audio-visual programmes seeks to explore their domestic and political role.

\section{Women Setting the Example: from Home Account Book to the Small Screen The Pedagogical Line for Women's Programmes}

There is no doubt that there was a "domestic morality for housewives" at work in television to accustom women to their new chores (Lévy 1995: 180). Some programmes for women took on a pedagogical role to teach women how to live in a 


\section{Corpus and Contextual Elements}

The documents I consulted come from the archives of the Institut National de l'Audiovisuel (INA). This public establishment was created in 1974 to archive audiovisual productions from the post-war period, and houses almost 60 years of public television recordings. A certain number of contextual details are required to grasp the rudimentary beginnings of television in France. It remained a public institution up until the creation of private channels in the 1980s. For some considerable time there was only one channel. As from 1949, Radiodiffusion-télévison française's (RTF) first channel (Première Chaîne) began broadcasting programmes, becoming the Office de radiodiffusion-télévision française (ORTF) in 1964, then TF1 as from 1975. The second channel (Deuxième Chaîne) was created in 1963, becoming Antenne 2 in 1975. In 1972, the third channel (Troisième Chaîne) saw the light of day, its name changing to FR3 in 1975. Compared with other countries, the number of homes equipped with television sets remained low until the 1970s. For example, there were 60,000 sets in France in 1953 (1 for every 704 inhabitants) as opposed to 22 million in the United States (1 for every 7 inhabitants); in 1961, France had 2,500,000 television sets (18\% of homes) as against 56 million in the USA ( 1 for every 3 inhabitants). It was not until 1976 that $85 \%$ of French homes boasted a television (Cazeneuve 1980: 49-50). Programmes nevertheless reached a wider audience than just television owners - French people went round to their neighbours to watch television, and sets were available in public places and in TV Clubs.

The corpus analysed for the purposes of this article was made up of 20 documents held by INA and broadcast between 1967 and 1981. This was a key period for the construction of large estates ${ }^{5}$ and for criticism of gender relations. These archives consist of documentaries and news reports (of between 5 minutes and 1 hour) based on investigations by television producers; they are the result of solid documentary work and are a precious source for sociological analysis.

The corpus allows us to grasp the differences between the approach to programmes aimed at women (Les femmes... aussi, Aujourd'hui Madame, Le magazine féminin, Vie pratique) and the approach to documentaries/reports for all audiences (l'Avenir est à vous, Journal Télévisé, Cinq colonnes à la Une, Affaire vous concernant, A la bonne heure, C'est la vie, Vivre au présent). When television first began, gender was a criterion for differentiating between audiences. Statistics showed that, on average, women spent more time watching television alone - in the mornings and afternoons. Paul F. Lazarsfeld and Frank N. Stanton describe different tastes, with women preferring programmes that were more oriented towards human interest and practical information (Lazarsfeld \& Stanton 1949).

\section{Method}

I began by watching the archived programmes with the sound muted, so as to concentrate on what I saw on the screen. At the intersection of class and gender, I studied the women's faces, their every gesture, the gender relations, as well as signifiers of low economic status and poverty (environment, flat, furniture, clothes, food) and. I then reversed the procedure and transcribed the audio track, to concentrate on the words and arguments used by the women in the documentaries. In this way I covered many different angles and distances of viewing and analysis. My analysis grid was as follows: how were the women portrayed as they managed their homes? What chores were shown? I compiled an inventory of these chores and on each occasion studied the manner in which they were filmed. I studied camera movements, the relationship between the words spoken and the pictures, and the effects of the editing. I use freeze-frame pictures to illustrate this article. 
modern home, look after a family, save time and be thrifty. Each programme offered short documentaries and provided practical advice, with proper lessons on housekeeping and home budgeting, as a way to pass on the powerful educational mission of social housing.

This was very much the approach adopted by the programme Vie pratique in April 1974, with a segment entitled "How to keep to budget" (Troisième Chaîne, "Vie pratique: Savoir tenir son budget", April 1 1974). For 26 minutes, the female audience could take a lesson in home economics. During the introduction, close-up shots showed a woman's hands holding a purse, paying at the supermarket check-out or signing a cheque [pictures 1-2-3]. This was followed by a documentary drama where a woman was doing her shopping. The calendar marches on: at the beginning of the month the shopping trolley is full, but at the end of the month she can only afford potatoes and sardines - basic products which signify poverty. She apologises as she serves dinner to her husband and children: "I wasn't able to stick to my budget".
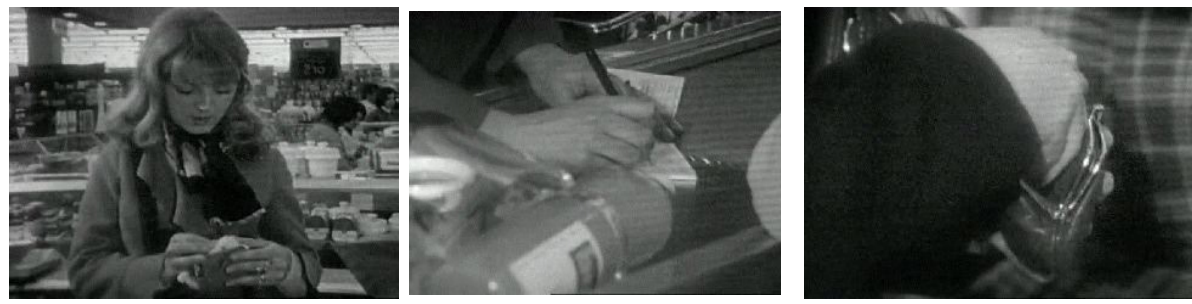

Picture 1-3 Troisième Chaîne, "Vie pratique: Savoir tenir son budget", April 11974

On the set, the female presenter begins her lesson on how to correct this behaviour: "you need to think before you spend (...)". She advises women who control the purse strings to avoid credits higher than $8 \%$ of income, and to calculate the utility and cost-effectiveness of household appliances [picture 4]. Her ideas are illustrated on the screen in the form of a lady who is looking sceptically at an electric toaster and tin opener - appliances that are unnecessary [picture 5]. The presenter warns viewers not to "blindly trust what adverts say".
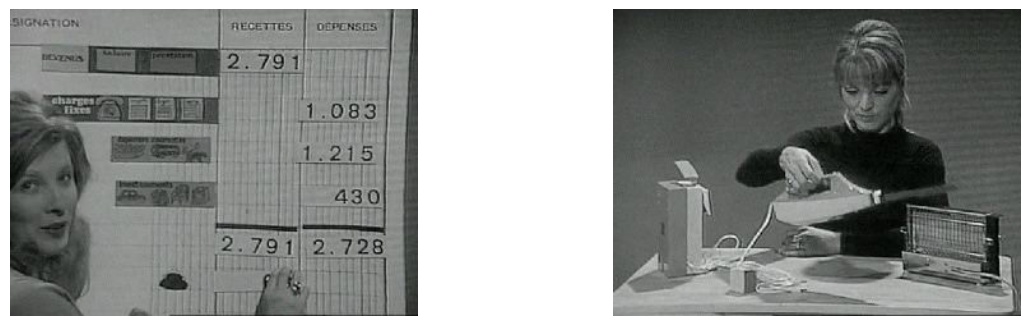

Picture 4-5 Troisième Chaîne, "Vie pratique: Savoir tenir son budget", April 11974 
Her main piece of advice is to keep accounts. The picture shows a woman opening a booklet entitled "My budget", with two columns: income/expenditure. One of these pages is reproduced on the set. The presenter gradually fills in the columns while pictures show us a woman concentrating on doing additions and subtractions in her account book [pictures 6-7]. The picture thus has a normative value (the proper way to do one's accounts) that is supported by what the presenter is saying. When it comes to the purchase of electrical appliances, the latter warns in a dramatic and moralistic tone: "if you are going to make purchases like that, you'll need to be as cunning as a fox".
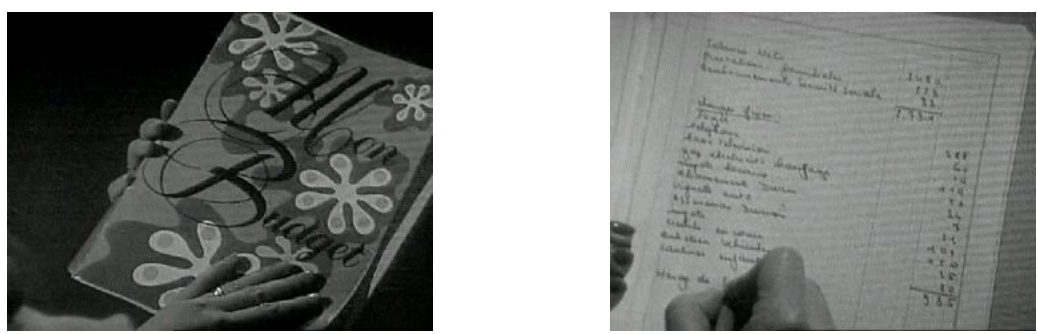

Picture 6-7 Troisième Chaîne, "Vie pratique: Savoir tenir son budget", April 11974

This account book was a tool for rationalising expenditure that had, since the interwar period, been widely distributed by home economics schools and by social assistance institutions who wished to ensure that child and housing benefits were put to proper use [picture 8].6 Such institutions employed "housekeeping advisors" (home economics specialists) who worked in social centres on the new

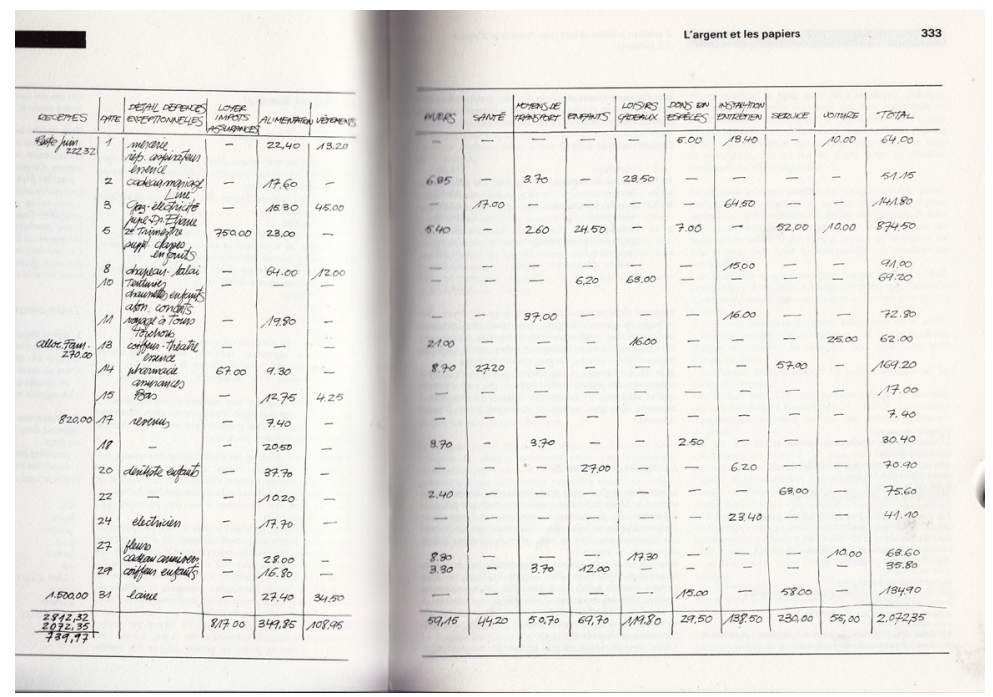

Picture 8 (1968) Encyclopédie de la maîtresse de maison, Paris: Club des amis du livre, 332-333. 
estates to supervise domestic budgets and help women from modest backgrounds to "better" spend and "better" manage their money.

Television programmes followed suit, making documentaries about this profession. As was the case with the programmes offering practical advice, the dissymmetrical relationships between the advisors and the women jumps right off the screen. The female professional either sits behind a desk to receive women, or else stands in front of a blackboard to give a lesson on the organisation of space at home. Taking a moralising stance, she explains the importance of budget management when one moves into social housing: "women burden themselves with debts, it's a very big problem. (...) as soon as they find themselves with more space, they want to buy furniture. And then there are the sales representatives who ring the doorbell... They've been dreaming of having a bedroom for years. But that is not what they should have bought." And the advisors give a series of directives: prioritise purchases, learn to do it yourself and get to know the cheapest shops (Première Chaîne, "Lavenir est à vous: Conseillère ménagère", March 16 1964).

In 1971, another report shows ten or so residents from a large estate sitting round a table and sewing (Première Chaîne, "Vivre au présent: Le budget familial", October 25 1971). The advisor asks: "Have you thought about your budget?". A young woman replies: "Budgets are a pipe dream. If at the end of the month you've made ends meet, then bravo! I can't!" The advisor retorts: "You nevertheless need to remember that every month you have fixed costs such as rent and food. So every month you need to

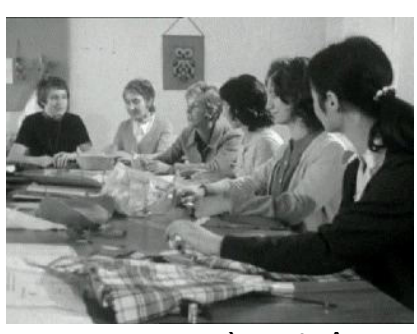

Picture 9 Première Chaîne, Vivre au présent: Le budget familial, October 251971. work out your income and your expenditure." [picture 9] The report ends with an interview with one of the participants. As this particular lady has put home economics tools into practice, the documentary uses her as a model. She shows her account book and a pie chart illustrating how her budget is divided. She is a highly organised woman who keeps all her bills neatly put away in a file [pictures 10-11-12].
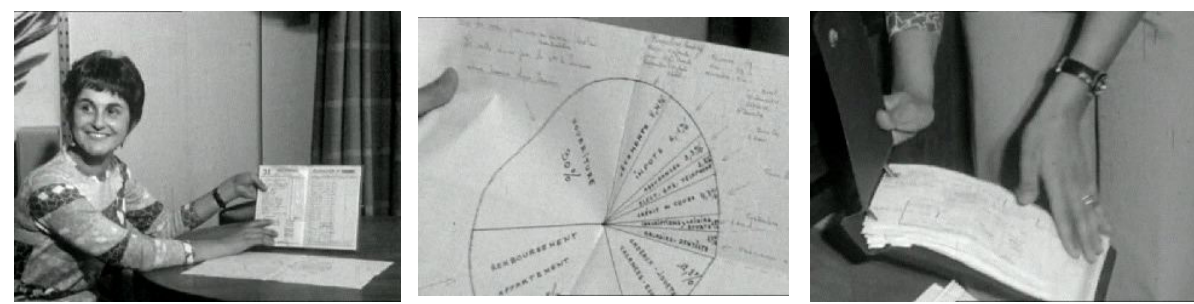

Picture 10-12 Première Chaîne, Vivre au présent: Le budget familial October 25 1971. 


\section{Money-management as a Real Job}

Such programmes aimed at women continued their budgetary education. Textual analysis reveals a clear pedagogic and normative thread throughout the documentaries and reports, which targeted the general public and was often televisually focused on the work involved in keeping an account book. A recurring motif includes the portrayal of conscientious working-class housewives doing the housework or shopping - and a voice-over listing various items in the family budget. The woman and the interviewer do their sums: expenses (rent, food, children and travel) and income (salary and social benefits). These programmes therefore allowed women's voices to be included, often expressing anxieties over daily money-management. They had apparently integrated "normative" standards - the family budget, the legitimacy of an account book, the fear and shame of getting into debt.

Nevertheless, although television gave specifically? working-class women a chance to be represented themselves, their calculations in front of the camera demonstrated the problems of poor families and their true economic competences.

One report in 1972, for example, on "those with less than 1,000 francs", follows Françoise (a widow and mother of three living in social housing) to the supermarket [pictures 13-14-15] (Deuxième chaîne, "JT 20h: Les moins de 1000 frcs", October 25 1972).
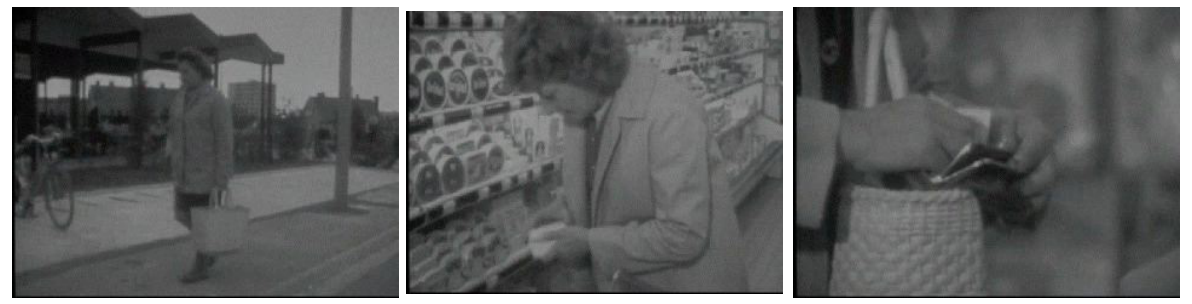

Picture 13-15 Deuxième chaîne, JT 20h: Les moins de 1000 frcs", October 251972.

She explains her budget: her salary as a sales assistant: 900 francs, ${ }^{7}$ child benefit: 970 francs, rent: 420 francs, less 220 francs of housing benefit. ${ }^{8}$ As a result, "when I do my shopping, I don't buy the minimum, I buy between the two. I do my sums so that I don't spend more than I should." At the supermarket, we see her ask the butcher the price of the calf's liver: "You don't have anything cheaper?" She finally settles for three slices of cow's liver... just for her children. It is nourishing. "I have to go without" she says. "I'll be honest with you, I live from day to day. I can't save money on my salary, what with my loan repayments. I buy on credit, I can't do it any other way." Françoise has taken the family budget norms on board and expresses the guilt she feels for having taken out loans and not being able to save. 
Another model of thriftiness is Mrs. Montagne, housewife, mother of 5, married to a worker and living in social housing in the Ardèche region (Deuxième chaîne, "Affaire vous concernant: couple pauvre", October 26 1981). The voice-over explains that she "looks after the home" and while she is doing the washing-up he talks to her about how she calculates her budget: "A dishwasher wouldn't be a useful expenditure. (...) It wouldn't be reasonable to buy one

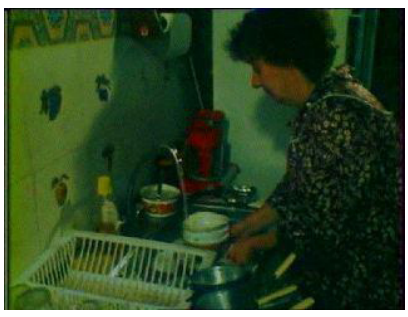
Picture 16 Deuxième chaîne,"Affaire vous concernant: couple pauvre", October 26 on our budget." Her children have given her useful 1981. gifts (a coffee maker and a yoghurt maker) [picture 16]. Mrs. Montagne does her shopping at the market, "it's the biggest item in the budget". By comparing prices, she saves 8 francs on a rabbit. The cameraman follows her to the baker's and zooms in on the bread price list for a few seconds to show just how much this basic product weighs on family budgets, even in 1981 - perhaps a way of demonstrating that the end of the post-war period makes it harder to balance the budget and thus complicates women's lives [pictures 17-18-19].
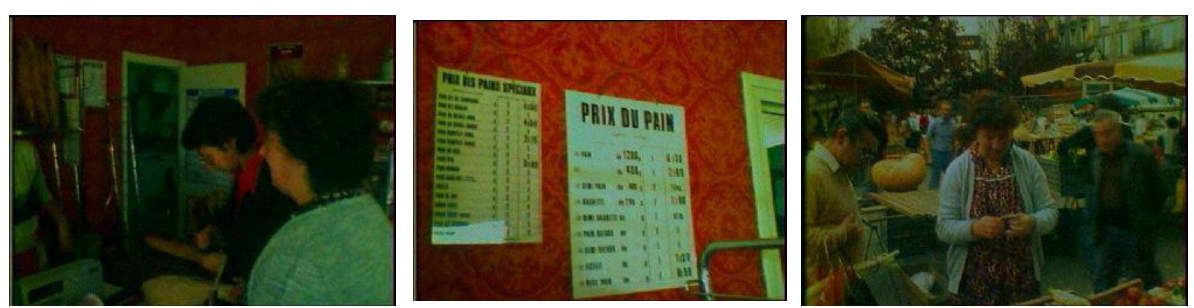

Picture 17-19 Deuxième chaîne,"Affaire vous concernant: couple pauvre", October 261981.

Calculations in front of the camera happen frequently in these television programmes, prompted by the common hardships of making ends meet - and despite the very earnest intentions behind affordable social housing programmes. As of 1954 social housing was allocated to low-income workers; those = with large families (over 3 children) had priority. Most tenants were low-ranked civil servants, employees, and blue-collar workers. ${ }^{9}$ Notwithstanding social benefits and new social housing, however, financial problems were widespread due to a significant proportional increase in the working-class family's budget being needed to cover rent. ${ }^{10}$ By the early 1970 s, some tenants were able to buy a suburban house and leave the high-rise estates. Gradually, those original tenants were replaced by poorer people. ${ }^{11}$ Yet meanwhile workers were the first victims of the deep recession: those remaining in social housing became unemployed and grew permanently poorer.

In their portrayals of these women, the journalists reveal the extent of women's chores with far more benevolence than is the case with the housekeeping 
advisor. They show how women do their best with such low salaries - more often than not lower than the average working-class salary, and with large numbers of children that they often have to raise on their own.

In 1967, the camera closes in for one minute on the hand of a lady who is rummaging through an old tin box full of buttons of all colours. She is trying to find four that match. Then a close-up of her fingers as she threads the needle (Première chaîne, "Les femmes...aussi: Micheline, 6 enfants, rue des Jonquilles", April 24 1967). Looking straight at the camera with a satisfied smile, she explains that "these are all buttons that I find in the street when I'm on my way to fetch my kids at their schools. I found these ones when I was walking to the Halles [wholesale market in Paris]. Everywhere. I always manage to find two of the same together. I've never bought buttons".

For 50 minutes this documentary follows Micheline, a 30-year-old resident of a tower block, mother of 6 , married to a worker. All of her everyday chores are filmed in great detail and often with no cutting, so as to emphasize the work involved (housework, shopping, sewing, children, washing, cooking). The button sequence is especially significant in terms of her thrift and her work as a homemaker.While she goes about her daily business, Micheline picks up second-hand buttons lost in the street. The seconds it takes her to collect and wash them allow her to save precious pennies. She can repair clothes so that they last longer. She continues with her accounts: "What costs me the most is the children. The clothes are less of an issue, because as I'm not afraid to admit, there are a lot of people who help me out. But it's the food. Some like this, others don't like that. My husband is verypicky, so that costs a fortune." She goes to the wholesale market, which is cheaper than the shops around the social housing tower blocks. She haggles, which once again helps her to save money. Budget management has to allow for individual particularities: the children's tastes and her husband's health problems. The budget "is my wife's business" says the latter, with an embarrassed smile. The film shows a ritual scene, an age-old practice in working-class families: the husband passing his weekly wage packet over to his wife [pictures 20-21]. The household operates in
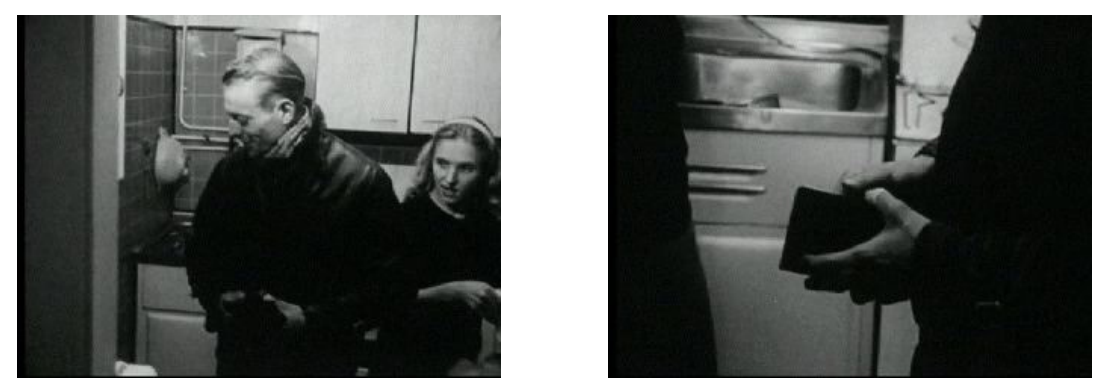

Picture 20-21 Première chaîne,"Les femmes...aussi: Micheline, 6 enfants, rue des Jonquilles", April 241967 
accordance with the breadwinner model: the husband goes to work, the wife looks after hearth and home (Potucheck 1997). Micheline earns a small wage that allows her to pay for the "holiday activity centre"12 for her children: she does the washing for other families. Finally, she tries to balance an ever-tricky budget by controlling family consumption - by not allowing her son to buy lemonade for example.

On the whole, for Micheline, Françoise, Mrs. Montagne and all the other, the archives show women who are constantly doing their sums. Responsibility for the household's economy comes across more as a complex burden than as a privilege. As women from modest backgrounds, they cannot afford to be negligent. The reports and documentaries thus present these women's task of money management as a job (Pahl \& Vogler 1994). Indeed, television uses close-ups when filming what the housewives do, just as it filmed, in those times, the detailed work done by workers and artisans. The camera systematically stays with them for several seconds in order to underline the women's hand-to-hand struggle with domestic finances: holding the purse, handling the coins and notes, examining the bills, counting the money, writing in the account book, sorting and filing the paperwork, scrutinising and comparing prices, touching and feeling the merchandise, carrying the shopping bag and rummaging through the accumulated second-hand treasure. From women's programmes to general viewing, for the very first time television was bringing into the limelight the domestic workload of women that had until then remained invisible.

It would seem that the television producers chose their models with care. ${ }^{13}$ "A family [of modest means] that seems to be able to make ends meet" says the schoolteacher of Micheline's children. His expert opinion and moral support are given during the first few minutes of the documentary: families do well in these new homes because women keep control of their households.

Nevertheless, money management cannot be reduced to mere submission to an economic rationale imposed from on high by institutions that control family budgets. The domestic economy is horizontal and is firmly tied to close social relations; these women activate a network of sociability that guarantees them resources and donations (this is particularly the case for Micheline, Françoise and another lady from Biarritz) and sometimes a secondary income (washing the neighbours' clothes) ("JT 20h: Une famille budget 800 frcs Biarritz", August 25 1970). Moreover, the women take the opportunity offered by the interviews to talk about their own moral economy ${ }^{14}$ which is defined in terms of individual situations. For example, Micheline makes the distinction between useful expenditure and superfluous expenditure. She prefers feeding her children to buying beauty products. While she sees make-up as "a waste of money", she does "not [systematically] disapprove of other people using it, such as a young woman with no family responsibilities. She simply points out that "I just don't have the time". She puts 
on a little lipstick on the rare occasions she goes out with her husband. Whilst make-up is certainly a matter of cost and morals, it is also a question of time: one needs time and opportunity to wear make-up. With her six children, Micheline has little of either.

Another example of moral economy is Mrs. Mercier, who has 6 children and who is separated from her husband who gives her no money. She has a disability pension and is unable to work. If she pays her rent, she cannot feed her children. The conclusion she has come to is that she cannot apply the budgeting rules: "it's impossible" (TF1,“A la bonne heure: qui habite les HLM?", May 22 1978). Then there is the couple who have made another decision; holding the debt file in her hands, the wife explains that they have trouble paying in September because they prefer to pay for their children to go on holiday so that they do not "hang around" in the streets and get into trouble [pictures 22-23] (TF1, "A la bonne heure", TF1, November 15 1976).
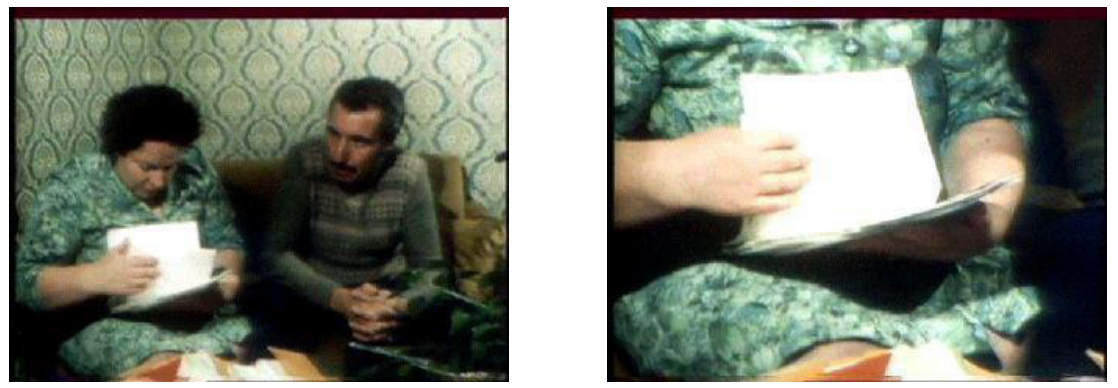

Picture 22-23 TF1, "A la bonne heure", November 151976.

We have established an initial picture of television in the post-war period - a television that was normative, a French institution, with the state simultaneously controlling the audiovisual world and social and family policies. Gender roles are clearly distinguished. Women are in the front line when it comes to keeping the accounts, finding resources and making savings. They are also at the origin of moral economies that contradict budgetary teachings. These "account book" documentaries nevertheless give them a platform for almost the entire duration of the reports. The women are not shown as mere budgetary strategists and performers of household tasks; they have a voice and they talk - not so much to the journalists as to the women who are watching. They are holding up a mirror and calling out to women who are in similar situations. When they punctuate their remarks with "you know...", they are talking to women who know how hard it is to make ends meet and to raise so many children. Their stories are relevant to other women. Expressing their views in this way to the camera, they are speaking to the public. They are thus encouraging and supporting the inner debates of the women 
listening to them in their social homes. This is clearly the objective of the television series Les Femmes... aussi - sixty-five documentaries produced between 1964 and 1973 by Éliane Victor. A way of talking to women about women, for almost an hour. "It wasn't a programme we watched for our entertainment" asserts Eliane Victor (Scatton-Tessier 2005: 977, 983). What was the result of the eruption and broadcasting of this discourse? In what way did it echo other public discourses by women belonging to social movements?

\section{Emancipatory Perspectives}

With these questions in mind, a different interpretation of the home-making, money-management and women theme becomes possible. My analysis of the corpus reveals clearly bifurcating lines: some documentaries let up on the educational pressure and examine more emancipatory perspectives which are representative of 1960's and 1970's politics: paid work and consumer protection associations.

\section{Women Active in the Workplace}

Other documentaries examine one of second-wave feminism's greatest demands: access to paid work. How can one properly "dwell", properly look after one's home and manage one's budget if one is working away from home? These documentaries reveal women's social insecurity, with low salaries, no childcare centres or social policies to support women at work, and the sharing of tasks within the family unit.

For example, in 1970, for 51 minutes the documentary Le prix du deuxième (television serie Les femmes...aussi) shows women calculating household finances in front of the camera and wondering if giving birth to a second child would be economically reasonable (Première chaîne, "Les femmes...aussi: Le prix du deuxième," February 11 1970). First segment: interview with a young woman called Arlette, holding her baby in her arms. She lives on a large estate. After having her second child, she has kept her job. For 2'52" the interviewer asks her about the family budget: the first child's school, the second child's nanny, travel, benefits and salaries. She is filmed up-close so that one can clearly see her facial expressions [picture 24]. When the sums have been completed, the interviewer's conclusion is unequivocal: "in fact there's no point in you working". After a few moments of silence, the young woman, surprised, opens her mouth to respond, but then changes her mind.

Finally she says that she had not taken account of the fact that she would lose her benefits when

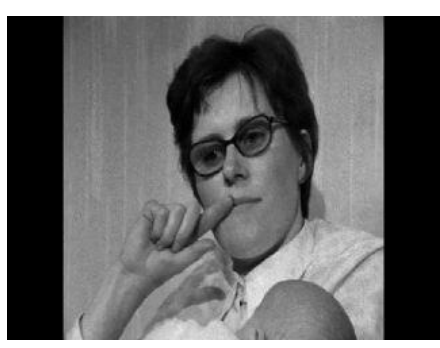

Picture 24 Première chaîne,"Les femmes...aussi: Le prix du deuxième," February 111970. 
she went back to work. "At the end of the day, I'm showing you that whether you work or not, the result is pretty much the same" says the journalist. Arlette pouts, her silence is eloquent ... she is trapped in her calculations, but her sceptical expression shows that as far as she is concerned the issue is elsewhere: one of continuing to have a job.

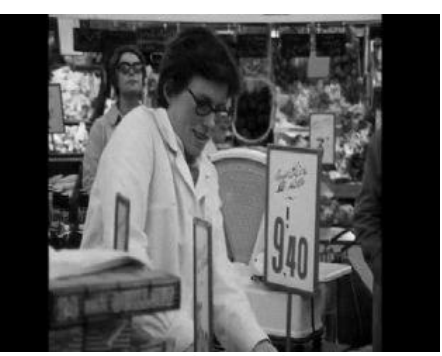

Picture 25 Première chaîne,"Les

Arlette is a sales assistant in a large grocery store. The pictures show her serving customers [picture 25] while her husband is interviewed at home. "She's the one who wants to work, she makes her own decisions. That doesn't mean she's unhappy at home, but she prefers being at work, she's been working in retail since she was 12 or 14." Yet while a factory manager who was interviewed said that the majority of women stop working after their second child, Arlette wanted to carry on working. Why?

"I told myself I'd never get this job back, because nowadays in retail there's no tenure." She wants to keep a job that she enjoys, a job where she has tenure, with economic and social security and perhaps a certain amount of financial independence. The law passed on 30 December 1966 allows women to stop work for one year after giving birth and obliges employers to take them back, but not necessarily in the same position. The fact of working has also allowed Arlette to create a progressive organisation of the home (her husband puts the baby to bed, takes it to the nanny, makes his own meals, accepts the fact that his wife works). This is therefore a different family model shown on television, one that is potentially a source of inspiration for female viewers. Several of the women filmed formulated other responses to the question "why go back to work?": because "we had a laugh" at work, because "you quickly get bored in social housing", because home-making is repetitive whereas "at work it's different". In another documentary from 1965, Ernestine give another answer: to do something that you yourself enjoy. She is expecting her fourth child and was offered social housing 6 months ago, after living for 5 years in a garden shed. Sitting on her bed, she tells the journalist that two years ago she had bought some bedroom furniture that she had kept in storage: "65,000 [old francs] second-hand. My husband was doing his military service, I was the one who bought it. I was working, so I managed to put the money aside". She smiles, happy, radiant, proud of the purchase that she made all on her own (Première Chaîne, "Cinq colonnes à la une: Ils ont trouvé un appartement", February 5 1965).

What solutions does the director of the film "Les prix du deuxième" suggest to make women's lives easier? First of all, during that period technological progress 
made it possible to reduce the number of hours worked. Anne-Marie, a typist with 3 children, works 36 hours a week ("achieved after many a long fight"). ${ }^{15}$ This union battle allowed all employees to retain the same retirement benefits. Secondly, a more radical proposal is that of a different social model. The documentary ends with pictures of parents dropping their children off at the childcare centre while a female doctor describes another model of society: "we might hope that both mother and father work less. And that the child spends its day in green spaces, spaces that are clean and nice. And that once the day's work is over, at around 4.30, mother and father come together to collect their child"[pictures 26-27].
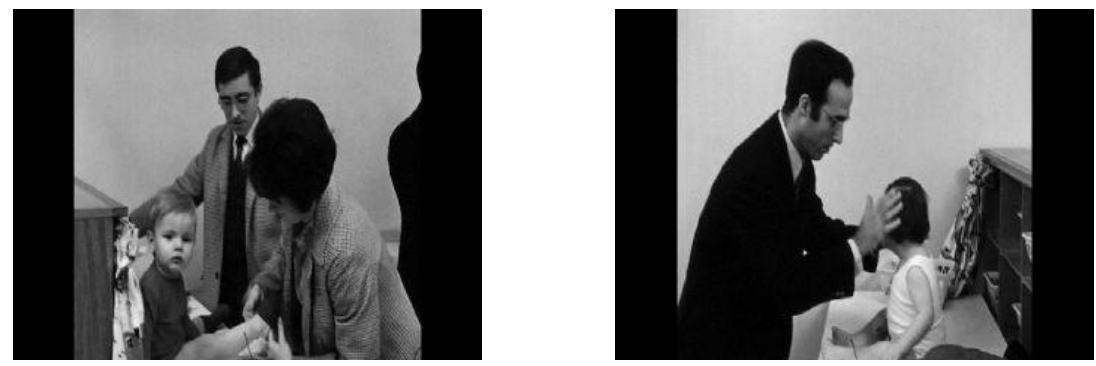

Picture 26-27 Première chaîne, "Les femmes...aussi: Le prix du deuxième," February 111970.

Freedom for women to work, fewer working hours for men and women with no loss of income, a sufficient number of quality childcare centres next to the tower blocks, fathers becoming involved in home life - all of these demands coincided with those of the feminist movement and were relayed by left-wing director Jacques Krier. Although the documentary looks inside women's account books and gets them to do their sums in front of the camera, this time the reason is not so much to focus on women's domestic responsibilities as to highlight those of public authorities which do not do enough to ensure social protection for women who wish to work. Certain responsibilities (amenity charges, household chores) need to be shared within the home, while others should be undertaken by public institutions. The home-making, money management and women theme becomes more complex; Jacques Krier demonstrates the need for men and social institutions as part of this trio.

\section{Women: Consumers up in Arms}

Women were in charge of the rent and as such were on the front line when there was an increase. They then needed to go out of the home, make their voices heard and sometimes even join organised social movements. To properly manage one's budget, one's home and one's family also means standing up for oneself and joining associations. 
The difficulties in paying the rent (constantly on the rise since the 1950s) encountered by social housing tenants throughout France led certain television programmes to devote entire reports to the problem (TF1, "A la bonne heure", TF1, November 15 1976). "Is there a social housing crisis?" asks the presenter of several segments in the A la bonne heure programme in 1976 - and it is women who reply [pictures 28-29]. First of all a female tenant, interviewed bread in hand, explains her budget: "We hang on in there, we hang on in, but people around here have a lot of problems with the bailiffs. Life is so hard. Even the most careful can no longer manage. I know that personally I never had debts, but I have to admit that since the start of this year I do have a few". At the supermarket, other inhabitants complain that the rise in social housing rents digs into the food budget: "once you've done your sums, there's not much left", "I can't do it. Just to feed the kids.
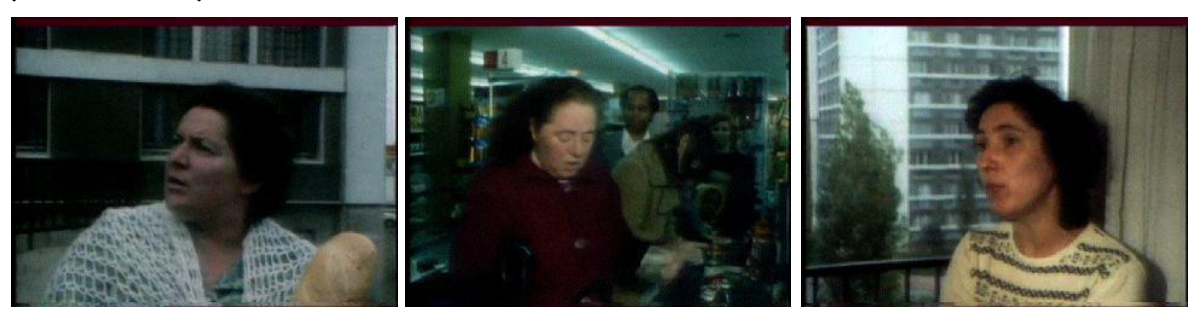

Picture 28-30 TF1, "A la bonne heure", November 151976.

My husband is a labourer, I have 5 children. I was behind with my rent. Bailiffs and ten grand in debts!" Another woman: "we make potato stews because we can't afford anything else".

Next, a woman is interviewed next to her window [picture 30]. Her face is marked, she is filled with emotion. Arms crossed, she talks about her debts, her voice cracks. Her husband has been ill, she has not made any payments for two months and the bailiffs came and threatened seizure. "This [debt] has been dragging me down for three years". As she talks through her budget, we understand why she cannot put any money aside; she is thus at the mercy of any tiny incident. By filming this woman close up, the cameraman demonstrates the full weight of being in charge of the budget - a moral weight that has physically marked her face. More than anything else, like the others, she speaks out to challenge the intransigence of the social landlord who simply does not care.

Other women are shy, not really daring to articulate any complaint. Like this retired woman living in La Courneuve in 1978 with her disabled son (TF1, "A la bonne heure: qui habite les HLM?”, TF1, May 22 1978). Weighed down by debts, the company in charge of social housing has offered her a cheaper but very dilapidated flat, with no heating or bathroom. "I just want a shower ... so we don't have to wash in the kitchen. I think those days are over now." She has made her point. Just a few words suffice to demonstrate the scandalous behaviour of the social landlord. 


\section{Culture Unbound}

Journal of Current Cultural Research

Social housing residents were regularly interviewed to protest against high rents. One example is Denise Girier, a tenant in Givors, whose husband is unemployed [pictures 31-32-33] (Antenne 2, "Antenne 2 Midi: Architecture HLM à Givors", July 2 1981). She is the one who deals with the rent and she is
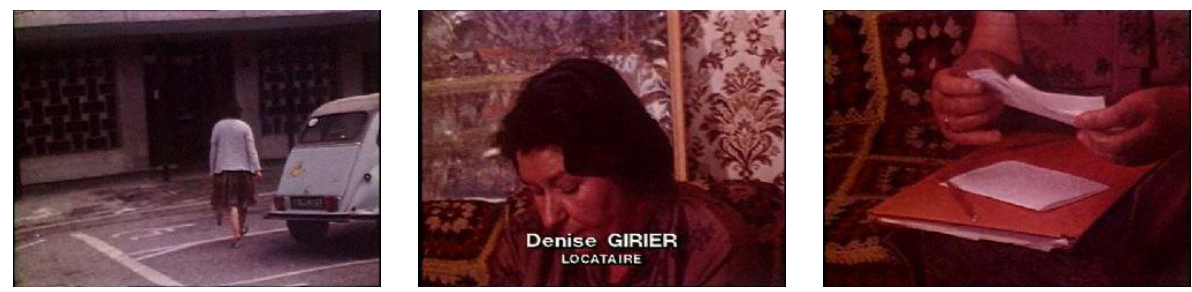

Picture 31-33 " Antenne 2 Midi: Architecture HLM à Givors", Antenne 2, July 21981.

filmed rent receipt in hand, protesting against the rise in heating charges; she explains that with support from the communist local authority, residents were able to block rent payments.

In 1980 in Argenteuil a woman lays four blankets over her baby in her pram [pictures 34-35]. She pays a huge amount for heating but their building is very damp. Another resident, member of the tenants association, is filmed with a bill in her hand; she explains that they have decided to block payment of amenity charges [pictures 36-37] (Deuxième Chaîne, "C’est la vie: loyer et charges Argenteuil", January 10 1980). There are several reports monitoring these avenues of protest.
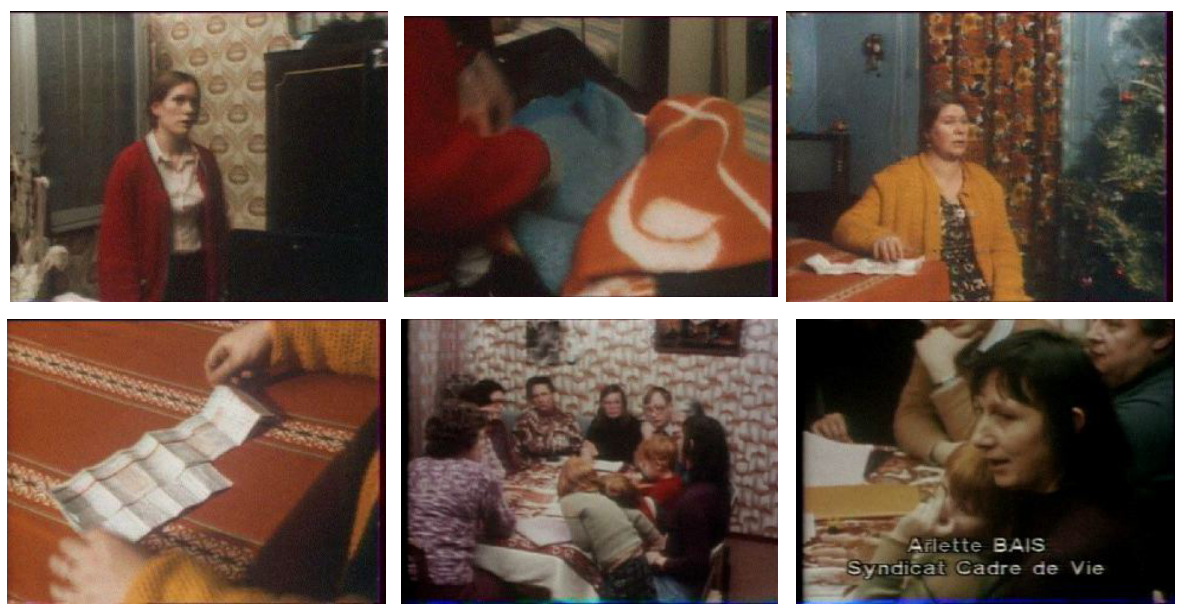

Picture 34-37 Deuxième Chaîne, "C'est la vie: loyer et charges Argenteuil", January 10 1980. Picture 38-39 Deuxième Chaîne, "C'est la vie", deuxième chaîne, January 11980.

For example, in 1980, one archive shows a tenants' meeting in a social housing 
flat in the north of France. One man, seven women and three children are present [pictures 38-39] (Deuxième chaîne, "C'est la vie", January 1 1980). This composition illustrates the tone of such movement: a meeting where women are in the majority and attend with their children - a composition similar to those of feminist groups and which departs from the traditional model of militant gatherings, pre1968, with a majority of men. The report revolves around Arlette Bais, a militant from the district community union. She explains how she telephones neighbours to sound the alert so that they can block bailiffs coming to expulse families who have not paid their rent. And how residents park their cars in front of the tower blocks to prevent lorries from coming to remove seized furniture.

In France, the 1970s saw the rise in political power of consumer protection associations. ${ }^{16}$ It was "district community" unionism - syndicalisme du cadre de vie in French - which covered everything that affected living conditions in the broadest sense: housing, the quality of public spaces, sports, cultural and social amenities, ecology, and the quality of consumer goods. Such movements were especially active on large housing estates, in an attempt to improve the quality of life. For local residents they represented first and foremost a pathway to socialisation, and secondly to politicisation. They encouraged women to speak out in public. In showing women who run public meetings and take action to block bailiffs, television reflected post-1968 transformations and a stronger female presence on the political stage. They became organisers of social life, taking charge of community issues - a task of a political nature that was anchored in everyday life.

In this respect archive analysis is more fruitful than the urban sociology of the time. Researchers who have studied district community unionism - and even more specifically its arrival in districts in the form of urban struggles ${ }^{17}$ - never mention the presence of women. French urban sociology of the 1960s and 1970s, behind the Marxist figures of Lojkine, Lefevbre and Castells, cared not a fig for social relationships of gender or for the new roles that women were taking on in the social world (Dagenais 1980). A deafening silence. The central place of women that was hidden by sociology texts, was revealed on the small screen. It was a real invasion - nothing but women on television! Directors' attention was occupied by women's faces, words and bodies.

\section{Calculating in Front of the Camera as Way to Become Public}

Post-war French television took a plurivocal view of ongoing social and urban changes: the development of large social housing tower blocks, the emancipation of women social movements within district communities and the evolution of domestic economies. Television can be normative just as it can reflect or even encourage the evolution of mores. 
Women's activities are tied to the welfare state which is revealed in all its complexity, controlling with one hand the rationalisation of domestic budgets and practices, and, with the other, improving living conditions and protecting individuals against vulnerabilities (Bock \& Thane 1994, Lewis 1992, Esping-Andersen 1990). Looking after the home meant juggling between account books, social amenities, the material comfort of the new homes, social benefits, community movements and arrangements between family members and neighbours. Women have to come to terms with all of these factors in order to look after the home.

First of all, and most significantly, this analysis of the history of television reveals just how heavily home-making and money management weighed on women. Both the reports and documentaries show that there was no respite from their work in the home. But how much of this work were men aware of in the 1960 s and 1970s?

Television reflected the deep social transformations and goalsof the postwar period: comfortable housing for all, social policies, women's emancipation, labour rights, growing consumerism, political movements. Its importance was profound. The audio-visual programmes studied in this review document the progress (with varying degrees of criticism) of the welfare state as it developed, spread and grew in significance. Film producers and directors were themselves influenced by this changing society. Their task was to show and explain these transformations, in concrete terms, to the French people. There were notable slippages: sometimes women's traditional roles and gendered values were represented; sometimes emancipation models and avant-garde ideas were advanced.

To conclude I will confine myself to emphasising two main research findings. Firstly, my study reveals the gendered dimensions of the welfare state. Housing and social policies were based on gender biases which replayed the labour and power divisions such as the dependence of women on men as bread-winners, women's domestic and family responsibilities. High-rise estates emphasised the economic dependency of women in the absence of transport, child care, employment, and activities other than domestic education. Women had to stay at home!

Nevertheless, some of these women used television to erase such boundaries when explaining their domestic and economic problems. Complaining on screen or joining consumer associations meant involvment in the public sphere to protest about their social conditions, via their particular experience of housekeeping and family life. Even if it was selective and limited participation, television accentuated and broadcast their voices to many homes across the country.

Other women that were filmed, such as Arlette (introduced above), were more radical in that they gave up home-making to work, became a union member, or told their husbands to cook. Moreover, district community unions (syndicalisme du cadre de vie) that developed in high-rise estates did not delimit the struggle for 
Women's emancipation to the domestic experience. They joined other struggles for contraception, abortion, and against racism (Overney 2019). Television became a megaphone for on-going social transformations and political movements.

Secondly, my analyses deconstruct the stereotypes relating to women and their domestic activities. They are consistent with works that have cross-cut the analysis of gender with the history of consumption (de Grazia \& Furlough 1996). Social sciences challenge the "separate spheres" ideology which caricatures consumption as purely feminine and production as purely masculine. These works show why consumption should not be considered as exclusively feminine and passive but as a dynamic process which is based on social relations and which generates them in turn. Television archives are useful material with which to examine the repressive or emancipatory effects of consumer society on women. Of course, in many of the programmes women embody the passive consumer: they do their shopping with their husband's money, do the housework and use the products and household appliances the merits of which have been extolled in television programmes for women. The pedagogical messages aimed exclusively at the female sex perpetuate the timeworn cliché that compares the spendthrift and gullible woman with the rational male consumer - an image that is very much present in Emile Zola's novel $\mathrm{Au}$ Bonheur des Dames (The Ladies' Delight) and that the these educational programmes take up for their own purposes: "if you are going to make purchases like that, you'll need to be as cunning as a fox".

My analysis of the corpus suggests that identities and gender and power relations can also be redefined through consumption. Firstly, the women are always filmed when in action, which destabilises the passive consumer model. They do their accounts, they touch and feel the merchandise and they compare prices at the supermarket. The documentaries put them under the spotlight. Secondly, these pictures put into perspective the notion of "depending on" one's husband. The man's salary is of course the household's principle source of income, but television highlights the behind-the-scenes work done by the women: savings made on small items, administrative claims, salvage, social benefits, and defence of moral economies. Finally, housing problems lead to speaking out in public. Television reveals women who on a daily basis adopt political stances that echo the demands of feminist movements. Women do their share to evolve these new towns.

Laetitia Overney, Associate Professor, École Nationale Supérieure d'Architecture Paris Belleville, UMR AUSser 3329 (Architecture, Urbanism, Society), is a sociologist. Her work involves studies of social housing, urban social movements and the 1960-1970 archives of the women's movement in France, such as personnal letters, almanacs, handbooks, papers, leaflets, television programmes. E-mail: laetitia.overney@laposte.net 


\begin{abstract}
Notes
${ }^{1}$ Influenced by C. Frederick's Anglo-Saxon domestic science (1919).

${ }^{2}$ Habitation à Loyer Modéré = low-rent social housing for people of low incomes.

${ }^{3}$ According to the 1954 census, $90 \%$ of French homes had neither shower nor bath, $73 \%$ had no inside lavatory and $42 \%$ had no running water (Insee: 1969).

${ }^{4}$ Thus, I am again taking up an idea suggested earlier by historians who have studied maternalism. The authors use the maternalism to describe how women in the U.S.A and western Europe use the language of motherhood to justify their involvement in the public sphere. The concept of maternalism is useful in analysing how women all over the world laid claim to social, civic and political rights and, thus, citizenship, via their particular experience of motherhood. (Gordon 1994, Van der Klein et al 2012)

${ }^{5}$ Construction increased in the late 1950 s to cope with the housing crisis, particularly through the development of ZUPs (zones to be urbanised as a priority). New districts sprang up in the form of huge estates of over a thousand homes, bearing the stamp of modern architecture. Construction reached its peak in 1973 with 556,000 homes built. ${ }^{6}$ Linda Gordon describes this kind of economic and moral supervision in the U.S.A from the end of the nineteenth century as well as the beginning of economic aid for poor women and children (discussing the supervision of household budgets, childrearing practices and the overall lifestyle of recipients). Her book sheds light on welfare programs that led directly to the view of the poor as inferior and unable to care for themselves and their children (Gordon, 1994). For an overview of the French historical context, see Isaac Joseph and Philippe Fritsch's research, which examines the supervision of poor families in France from the second half of the eighteenth century onwards (Joseph \& Fritsch, 1977).

${ }^{7}$ The documentary concerns people who earn less than one thousand francs a month, i.e. equivalent to the average salary of a female worker in 1972 (969 francs) and less than the average salary for a male worker (1403 francs) (Baudelot \& Lebeaupin, 1979: 17).

${ }^{8}$ In France, there are two ways to finance social housing: on one hand, by granting funds to social-housing landlords for the construction, on the other hand, by paying a benefit to the tenant to cover a part of the rent.

${ }^{9}$ The housing crisis was so serious in France in the early 1960s that even the middle class had difficulties finding a stable and pleasant place to live.

${ }^{10}$ Sociologist Michel Verret provides certain figures for France: in 1951, expenditure on the home accounted for $8 \%$ of the working-class budget (deteriorated housing with low rents), rising to $18.1 \%$ in 1972 (Verret 1979: 28).

${ }^{11}$ For example, from 1971, the French State imposes 30\% of social housing reserved for poor families among new social housing built in the Paris region. Journal Officiel, june 51971.
\end{abstract}




\section{Culture Unbound}

Journal of Current Cultural Research

${ }^{12}$ "Patronage" in French. An activity centre for children run by the Catholic church during the school holidays.

${ }^{13}$ There is no information in the archives about the making of the programmes. Eliane Victor leads one to suppose in her book that the women were found by word of mouth (Victor 1973: 11), for example among the film director's acquaintances.

${ }^{14}$ Thompson, a historian specialising in the $18^{\text {th }}$ century, used the notion of moral economy to describe a community's economic values and practices. The complex nature of this notion has been discussed for some time (Thompson 1971), (Fassin 2009). Without wishing to continue the debate in this article, I use the term moral economy to underline poor people's ability to determine what is or is not acceptable, what is right and fair, and to orient their acts in accordance.

${ }^{15}$ The legal duration is 40 hours.

${ }^{16}$ This was the beginning of consumer protection laws - such as the 1972 law regulating doorstep selling.

${ }^{19}$ Militants protested against insalubrious housing, rising rents, gentrification and the destruction of social venues; they supported an urbanism that listened to inhabitants. For a presentation of these struggles, see (Miller 2003).

\section{References}

"JT 20h: Une famille budget 800 frcs Biarritz", August 251970.

Antenne 2, “Antenne 2 Midi: Architecture HLM à Givors", July 21981.

Baudelot, Christian \& Anne Lebeaupin (1979): “Les salaires de 1950 à 1975," Économie et statistiques, 113: 1, 15-22.

Bock, Gisela \& Pat Thane (eds) (1994): Maternity and Gender Policies. Women and the Rise of the European Welfare State 1880s-1950s, London \& New York, Routledge.

Caigny de, Sofie (2005): "Catholicism and The Domestic Sphere: Working-Class Women in Inter-war Flanders," Home Cultures, 2: 1, 1-24.

Canteux, Camille (2014): Filmer les grands ensembles, Paris: Créaphis.

Cazeneuve, Jean (1980): Sociologie de la radio-télévision, Paris: Presses Universitaires de France.

Clarke Jackie (2005): "L’organisation ménagère comme pédagogie. Paulette Bernège et la formation d'une nouvelle classe moyenne das les années 1930 et 1940," Travail, genre et sociétés, 13, 139-157.

Dagenais, Huguette (1980): "Les femmes dans la ville et dans la sociologie urbaine: les multiples facettes d'une même oppression," Anthropologie et sociétés, 4:1, $21-36$.

Deuxième chaîne, "Affaire vous concernant: couple pauvre",October 261981.

Deuxième chaîne, "C'est la vie: loyer et charges Argenteuil", January 101980.

Deuxième chaîne, "C'est la vie", January 11980.

Deuxième Chaîne, "JT 20h: Les moins de 1000 frcs", October 251972.

Esping-Andersen, Gosta, (1990): The Three Worlds of Welfare Capitalism, Cambridge: Polity Press.

Fassin, Didier (2009): “Les économies morales revisitées'," Annales. Histoire, Sciences sociales, 64: 6, 1237-1266.

Frederick, Christine (1919): Household engineering. Scientific Management in the 


\section{Culture Unbound}

Journal of Current Cultural Research

home, Chicago: American school of home economics.

Gordon, Linda (1994): Pitied But Not Entitled: Single Mothers and the History of Welfare, London: Free Press.

Grazia de, Victoria \& Elen Furlough (eds) (1996): The Sex of Things: Gender and Consumption in Historical Perspective, Berkeley: University of California Press.

Hoggart, Richard (1957): The Uses of Literacy: Aspects of Working Class Life, London: Chatto and Windus.

INSEE (1969): Résultats préliminaires du recensement de 1968: démographie générale, population active, ménages, logements, Paris: Insee.

Joseph, Isaac \& Philippe Fritsch (1977): Disciplines à domicile: l'édification des familles, Fontenay-sous-Bois: Recherches.

Lazarsfeld Paul F. \& Franck N.Stanton (1949): Communications research 1948-1949, New York: Harper \& Brothers.

Lévy Marie-Françoise (1995): “Famille et télévision 1950-1986," Réseaux, 72-73, 177-193.

Lewis, Jane (1992): “Gender and the Development of Welfare Regimes," Journal of European Social Policy, vol. 2 (3), 159-73

Miller, Micheal James (2003): The Representation of Place: Urban planning and protest in France and Great Britain, 1950-1980, Farnham: Ashgate.

Overney, Laetitia (2019): "Les archives féministes du logement social: une mémoire discrète et émiétée," Bard, Christine, (ed.) Les féministes et leurs archives (19682018), Rennes: Presses Universitaires de Rennes, upcoming book.

Pahl Jan \& Vogler Carolyn (1994): "Money, power and inequality within marriage," The Sociological Review, 42: 2, 2363-288.

Potucheck, Jean-L., (1997): Who Supports The Family? Gender and Breadwinning in Dual-Earner Marriages, Redwood City: Standford University Press.

Première Chaîne, "Vivre au présent: Le budget familial”, October 251971.

Première chaîne, "Cinq colonnes à la une: Ils ont trouvé un appartement", February 51965.

Première Chaîne, "L'avenir est à vous: Conseillère ménagère”, March 161964.

Première chaîne, "Les femmes...aussi: Le prix du deuxième," February 111970.

Première chaîne, "Les femmes...aussi: Micheline, 6 enfants, rue des Jonquilles", April 241967.

Première Chaîne, "Vivre au présent: Le budget familial", October 251971.

Rudolph, C. Nicole (2014): At home in Postwar: Modern Mass Housing and the Right to Comfort, New-York: Berghahn Books.

Scatton-Tessier, Michelle (2005): "Rencontre avec Eliane Victor, la Grande Dame de la télévision française," The French Review, 78 : n5, 976-987.

Segalen, Martine (1994): “The Salon des Arts Ménagers, 1923-1983: A French Effort to Instil the Virtues of home and Norms of Good Taste," Journal of Design History, VII, 267-75.

TF1, “A la bonne heure: qui habite les HLM ?”, May 221978.

TF1, “A la bonne heure: qui habite les HLM ?”, May 221978.

TF1, "A la bonne heure", TF1, November 151976.

TF1,"A la bonne heure", November 151976.

Thompson, Edward Palmer (1971): "The moral economy of the English crowd in the eighteenth century," Past and Present, 50, 76-136.

Troisième Chaîne, "Vie pratique: Savoir tenir son budget", April 11974.

Verret, Michel (1979): L'espace ouvrier, Paris: Armand Colin.

Victor, Eliane (1973): Les femmes...aussi, Paris: Mercure de France.

Van der Klein, Marian, Plant, Rebecca, Sanders, Nichole, \& Lori Weintrob (eds) (2012): Maternalism Reconsidered: Motherhood, Welfare and Social Policy in the Twentieth Century, New-York: Berghahn Books. 